\title{
The Effect of Environmental and Social Performance on the Stock Performance of European Corporations
}

\author{
Andreas Ziegler · Michael Schröder · Klaus Rennings
}

Published online: 2 October 2007

(C) Springer Science+Business Media B.V. 2007

\section{Erratum to: Environ Resource Econ (2007) 37(4): 661-680 DOI: 10.1007/s10640-007-9082-y}

The email address of Andreas Ziegler should be andreas.ziegler@ccrs.unizh.ch The affiliation of Klaus Rennings and Michael Schröder is:

Zentrum für Europäische Wirtschaftsforschung (ZEW) L 7, 168161 Mannheim, Germany Email: schroeder@zew.de, rennings@zew.de

The online version of the original article can be found under doi:10.1007/s10640-007-9082-y.

A. Ziegler $(\bowtie)$

Center for Corporate Responsibility and Sustainability, The University of Zurich, Künstlergasse 15a, 8001, Zurich, Switzerland

e-mail: andreas.ziegler@ccrs.unizh.ch

M. Schröder · K. Rennings

Zentrum für Europäische Wirtschaftsforschung (ZEW), L 7,1, 68161 Mannheim, Germany

e-mail: schroeder@zew.de

K. Rennings

e-mail: rennings@zew.de 